\title{
Organic horticulture: a current demand, whose proper management is the only guarantee of safe food
}

\author{
Fernanda Pinto-Ferreira * \\ Roberta Lemos Freire \\ Eloiza Teles Caldart \\ Aline Ticiani Pereira Paschoal \\ Gabriela Bahr Arias \\ Winni Alves Ladeia \\ Regina Mitsuka-Breganó \\ Italmar Teodorico Navarro \\ Universidade Estadual de Londrina \\ Rodovia Celso Gracia Cid, PR 445- Km 388 \\ Caixa Postal 10.011-000, CEP 86057-970, Londrina - PR, Brasil \\ * Autor para correspondência \\ nandaferreiravet@gmail.com
}

Submetido em 23/11/2018

Aceito para publicação em 06/05/2019

\section{Resumo}

Horticultura orgânica: uma demanda atual, cujo manejo adequado é a única garantia de alimento seguro. O estudo foi realizado entre julho de 2014 e maio de 2016, em 21 propriedades hortícolas do estado do Paraná, Brasil. Foram coletadas duas amostras de vegetais folhosos e uma amostra de água de irrigação por propriedade. As amostras de água foram analisadas pela técnica do substrato cromogênico para avaliar a contaminação por coliformes totais e Escherichia coli, e os vegetais foram avaliados pelas técnicas de Willis (1921), Hoffman et al. (1934), Faust et al. (1939) e quanto à contaminação por parasitas. Observou-se presença de E. coli em 80,95\% (17/21) das amostras de água; com relação aos vegetais, 19 (45,23\%) continham pelo menos uma espécie de parasita, tais como: ancilostomatídeos, Chilomatix spp., Dipillidium spp., Entamoeba spp., Strongyloides spp., Trichuris spp., larva de vida livre, larva de nematódeo, oocisto não-esporulado. Houve associação estatística entre o destino do esgoto (fossa seca) e a positividade aos parasitas. Os dados mostram contaminação fecal em número significativo de amostras e confirmam a necessidade de maiores exigências sanitárias durante o cultivo de hortaliças folhosas, que, na maioria das vezes, são consumidas cruas.

Palavras-chave: Escherichia coli; Helminto; Parasita; Protozoário

\section{Abstract}

The objective of this study was to evaluate the contamination by Escherichia coli in irrigation water and parasites in leafy vegetables cultivated in small organic horticultural properties and to investigate the critical points 
during cultivation. The study was carried out between July 2014 and May 2016 in 21 horticultural properties in the state of Paraná, Brazil. Two samples of leafy vegetables and one sample of irrigation water were collected per property. Water samples were analyzed by the chromogenic substrate technique to evaluate contamination by total coliforms and Escherichia coli, and the vegetables were evaluated by the techniques of Willis (1921), Hoffman et al. (1934) and Faust et al. (1939) for parasite contamination. The presence of E. coli was observed in $80.95 \%(17 / 21)$ of the water samples; with respect to vegetables, $45.23 \%(19 / 42)$ contained at least one parasite species, such as: hookworms, Chilomatix spp., Dipyllidium spp., Entamoeba spp., Strongyloides spp., Trichuris spp., nematode larva, non-sporulated oocyst. There was a statistical association between the fate of the sewage (cesspool) and the positivity to the parasites. The data show fecal contamination in a significant number of samples and confirm the need for greater sanitary requirements during the cultivation of leafy vegetables, which are mostly consumed raw.

Key words: Escherichia coli; Helminth; Parasite; Protozoan

\section{Introduction}

Organic products have been preferred by consumers because they are associated with a production system that avoids or excludes the use of industrialized chemicals such as synthetic fertilizers, growth regulators and pesticides or agrochemicals (SANTANA et al., 2006; ABREU et al., 2016). On the other hand, there is growing concern about the risk of infection by enteroparasites, since many raw vegetables are served for human consumption, thereby contributing to the oral transmission of these parasites (ESTEVES; FIGUEIRÔA, 2012).

Endoparasites are cosmopolitan and endemic in third-world countries and represent an important problem in public health. They are acquired by ingestion of infective forms contained in contaminated food or water (CACCIÒ et al., 2018). When consumed raw, vegetables can serve as a transmission via (VOLLKOPF et al., 2006; FERREIRA et al., 2018). The cultivation conditions, including quality of irrigation water, the type of fertilizer used, the storage conditions, transport and handling of the crop by the producer are directly related to this contamination (PACHECO et al., 2003).

The objective of this study was to evaluate the contamination by Escherichia coli in irrigation water and parasites in leafy vegetables cultivated in small organic horticultural properties and to investigate the critical points during cultivation.

\section{Material and Methods}

The study was carried out from July 2014 to May 2016 at horticultural properties in the municipalities of Apucarana, Marilândia do Sul, Ortigueira, Rolândia and Londrina (District Guaravera), in the state of Paraná (Figure 1). Small commercial organic leafy vegetable production properties assisted by the Organic Certification Project of the State University of Londrina were included in analyses.

Forty-two clumps of leafy vegetables were collected (two per property), packed in plastic bags and kept under refrigeration. For detection of helminths, $500 \mathrm{~mL}$ of Glycine $1 \mathrm{M}$ and $100 \mathrm{~g}$ of the vegetables were homogenized in a plastic bag, manually shaken for 10 minutes, filtered through double gauze, collected in a conical chalice, and allowed to settle for $12 \mathrm{~h}$. Then, $20 \mu \mathrm{L}$ of the sediment was observed under an objective microscope at 40x (HOFFMAN et al., 1934). The supernatant was removed from the chalice with a pipette, the pellet was centrifuged at $1120 \mathrm{x} \mathrm{g}$ for 5 minutes. With the final sediments (approximately $0.5 \mathrm{~mL}$ ) slides stained with Lugol's iodine (MATOSINHOS, 2012) were mounted to facilitate the detection and identification of eggs and larvae under an optical microscope.

For detection of protozoa, $50 \mathrm{~g}$ of the vegetables and $300 \mathrm{~mL}$ of Tween 80 (1\%) solution were placed in a plastic bag and homogenized with a stirrer for three minutes. Subsequently, the solution resulting from the first step was filtered through double gauze into a 
FIGURE 1: Map of the state of Paraná highlighting the municipalities of Apucarana, Londrina, Marilândia do Sul, Ortigueira and Rolândia, sampling sites of vegetables and water subjected to parasitological and microbiological evaluation, from 2014 to 2016, Paraná, Brazil.

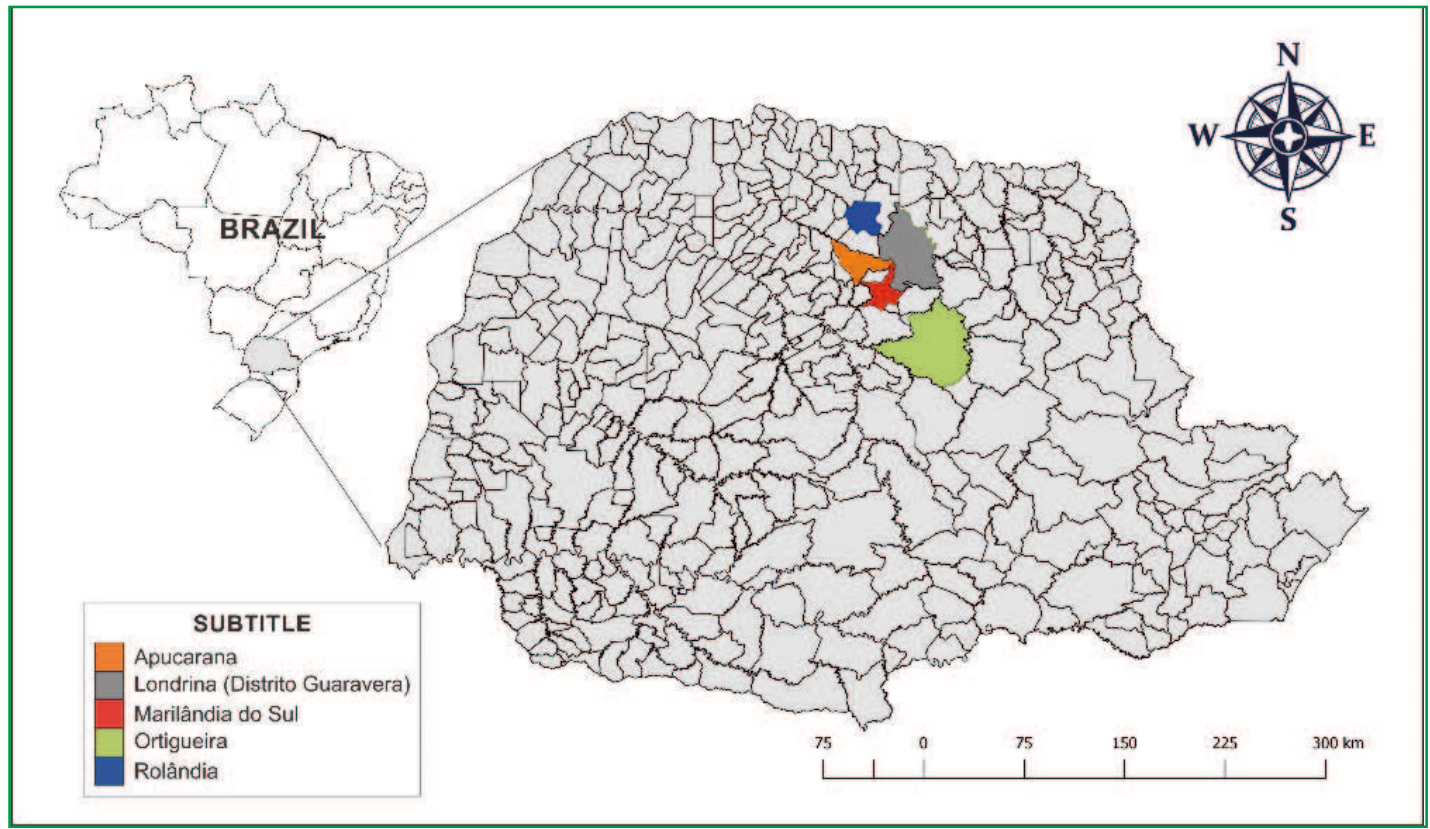

500-mL glass beaker. The filtered extract was divided into tubes and centrifuged at $2100 \mathrm{x} \mathrm{g}$ for 10 minutes each time (CARELI, 2009). Approximately $5 \mathrm{~mL}$ of the extract was processed and observed by the technique of Willis (1921) and Faust et al. (1939).

The microbiological analysis was performed using the chromogenic substrate technique, according to the manufacturer's recommendation (Colilert, Idexx, Westbrook, Maine, EUA), the results are expressed as NMP/100 mL (most probable number of total coliforms or Escherichia coli per $100 \mathrm{~mL}$ of water), 21 water samples (one per property) were collected directly from the irrigation tap of the gardens vegetables, as recommended by Brazilian protocol (BRASIL, 2013).

A semi-structured questionnaire was applied to all horticulturists participating in the study, with questions regarding the type of planting and fertilization, soil supplementation, use of pesticides, presence of animals on the property, irrigation system and characteristics of the bathroom and sewage. This work was approved by the Research Ethics Committee Involving Human
Beings of the State University of Londrina under number $2,481,228$.

The program EpiInfo 3.5.4 (DEAN, 1990) was used to tabulate the variables together with the microbiological and molecular results. Statistical analyzes were performed using the EpiInfo 3.5.4 and $\mathrm{R}$ 3.4.1 programs (R CORE, 2003) using the Chi-square test or Fisher's exact test, when appropriate. The data were compared using odds ratios (ORs) with confidence intervals (CIs) of 95\%, significance level of $5 \%$.

\section{Results}

A total of 42 samples of vegetables and 21 water samples were collected from 21 properties in the municipalities of Apucarana (5/21), Marilândia do Sul (8/21), Ortigueira (6/21), Rolândia (1/21) and Londrina (District Guaravera) (1/21). Among the vegetables, 19 samples were of lettuce (Lactuca sativa), nine were chicory samples (Cichorium endivia), seven were arugula samples (Eruca sativa), five were chives samples (Allium fistulosum), one was a spinach samples (Spinacia 
oleracea) and one was a chard sample (Beta vulgaris subsp. vulgaris).

Eighteen properties were certified for organic cultivation, and three (14.28\%) were in the certification phase. The organic fertilizer source was variable among the properties: eight (38.09\%) used cow manure, seven (33.33\%) used chicken manure, three (14.28\%) used mixed manure (chicken and cow) and three (14.28\%) used a commercial compound. Nine properties were regularly supplemented with mineral soil, six with limestone $(66.67 \%)$, and three with potassium supplement (33.33\%). Domestic animals, such as dogs, cats, horses, cattle, were present in all properties studied and, in four (19.04\%) of them, the animals had access to the gardens.

Wild animals (deer, hares, skunks, felines and birds) were present in all properties. All the properties performed vegetable washing - $11(52.38 \%)$ in treated tap water and $10(47.61 \%)$ in rinsing tanks. The irrigation was manual in nine (42.85\%) and automated in 12 (57.14\%) properties; the source of water for irrigation in $12(57.14 \%)$ properties was from mines, three (14.28\%) from rivers and six $(28.57 \%)$ from artesian wells.

Water analysis showed that $18(85.71 \%)$ had total coliforms (CT) ranging from 1 to $>2419,6 \mathrm{CTNMP} / 100$ $\mathrm{mL}$, among these, 10 were mine water, five artesian well and three of river samples. Regarding the presence of Escherichia coli, 17 (80.95\%) samples were positive, varying from 1 to $218.7 \mathrm{NMP} / 100 \mathrm{~mL}$, among them, nine were from mine water, five from artesian wells and three from rivers.

Among the properties visited, 71.4\% (15/21) had at least one sample contaminated by parasites. In relation to the methods used for parasitological research, $13(30.95 \%)$ vegetables samples were positive in the Hoffman et al. (1934) technique, 5 (11.90\%) in the Faust et al. (1939) technique, $5(11.90 \%)$ in the Willis (1921) technique and $19(45.23 \%)$ were positive in at least one of the three parasitological techniques used in the present study. The results are detailed by property, vegetable and parasite found in Table 1. When considering positivity in at least one of the parasitological methods, a statistically significant difference was observed in the fate of the sewage variable $(p=0.045)$, with the cesspool being the most positive sewage destination.

\section{Discussion}

In the study, the presence of $E$. coli was observed in $17(80.95 \%)$ of the analyzed water samples, of which three $(17.65 \%)$ levels higher allowed by CONAMA (National Environment Council) (CONAMA, 2005). Resolution 357/05 recommends that, for the irrigation of raw vegetables and fruit that have yet to fully develop, a CTT count of less than $200 / 100 \mathrm{~mL}$ is appropriate. Escherichia coli is a facultative, anaerobic gram-negative bacteria, commensal in the intestinal microbiota; besides being the main indicator of fecal contamination (CONAMA, 2005), it can often become an opportunistic pathogen (NATARO; KAPER, 1998; FRANCO; LANDGRAF, 2003). It is known that the contamination of vegetables by pathogenic microorganisms is directly related to the quality of irrigation water (SCHERER et al., 2016), so it is imperative that this type of water be of high quality, passing through prior treatment, when necessary. The E. coli contamination has also been previously described in irrigation water in conventional cultive (SCHERER et al., 2016; SILVA et al., 2016a), which confirms that regardless of the type of cultive, water can be an important pathway for the transmission of pathogens, and chlorination is an efficient technique for the killing of bacteria and viruses.

Among the protozoa found, Chilomatix spp. and some species of Entamoeba spp. are commensal protozoans, even if not pathogenic, they indicate fecal contamination of human origin (OLIVEIRA; GERMANO, 1992). Entamoeba histolytica is important to public health due to its high pathogenicity and cyst resistance to conventional water treatment (MELO et al., 2004; MONTANHER et al., 2007). Arbos et al. (2010) suggested that the presence of parasitic structures in vegetables is due to improper cultivation, with respect to hygiene, either through irrigation water, access of wild or domestic animals to gardens and/or, the use of fertilizers with insufficient composting time.

Samples with non-sporulated oocysts were observed. It was not possible to confirm the species 
TABLE 1: Results of the Faust et al. (1939), Hoffman et al. (1934) and Willis (1921) parasitological techniques from samples of vegetables from organic farm properties in Paraná, Brazil, from 2014 to 2016.

\begin{tabular}{|c|c|c|c|c|c|c|c|}
\hline Property & Municipality & $\begin{array}{c}\text { Faust } \\
\text { et al. (1939) }\end{array}$ & Parasite & $\begin{array}{l}\text { Hoffman } \\
\text { et al. (1934) }\end{array}$ & Parasite & $\begin{array}{l}\text { Wiilis } \\
\text { (1921) } \\
\end{array}$ & Parasite \\
\hline 1 & Mar. Sul & - & & - & & - & \\
\hline 2 & Mar. Sul & - & & $\begin{array}{l}+ \text { Let } \\
+ \text { Aru }\end{array}$ & Chil, Ent, MiE & - & \\
\hline 3 & Mar. Sul & - & & + Aru & OoN & $\begin{array}{l}+ \text { Let } \\
+ \text { Aru }\end{array}$ & OoN, Ent, NeL \\
\hline 4 & Mar. Sul & - & & - & & + Let & $\mathrm{NeL}$ \\
\hline 5 & Guaravera & + Let & Ent & + Aru & MiE & + Aru & MiE \\
\hline 6 & Ortigueira & - & & + Chi & Ent & - & \\
\hline 7 & Ortigueira & - & & - & & - & \\
\hline 8 & Ortigueira & + Let & Str, Ent & + Let & OoN & - & \\
\hline 9 & Ortigueira & - & & - & & - & \\
\hline 10 & Ortigueira & - & & - & & - & \\
\hline 11 & Ortigueira & - & & + Let & Ent & - & \\
\hline 12 & Rolândia & - & & + Chi & Dipil & - & \\
\hline 13 & Apucarana & + Chi & Hoo & - & & - & \\
\hline 14 & Apucarana & - & & - & & + Let & Trich \\
\hline 15 & Apucarana & - & & + Let & Str & - & \\
\hline 16 & Apucarana & - & & - & & - & \\
\hline 17 & Apucarana & - & & - & & - & \\
\hline 18 & Mar. Sul & $+\mathrm{Chi}$ & Ent & + Chd & $\mathrm{MiE}$ & - & \\
\hline 19 & Mar. Sul & + Chi & Ent & + Chi & $\mathrm{NeL}$ & - & \\
\hline 20 & Mar. Sul & - & & + Let & Lar & - & \\
\hline 21 & Mar. Sul & - & & $+\mathrm{Chv}$ & $\mathrm{NeL}$ & - & \\
\hline
\end{tabular}

*+ positive sample;-negative sample. Chd: Chard; Let: Lettuce; Chv: Chive; Chi: Chicory; Aru: Arugula. MiE: Mite egg; Hoo: hookworms; Chil: Chilomatix spp.; Dipil: Dipillidium spp.; Ent: Entamoeba spp.; Str: Strongyloides spp.; Lar: free-living larva; NeL: nematode larva; OoN: non-sporulated oocyst; Trich: Trichuris spp.

identity through sporulation; however, it is important to consider that several parasites pathogenic to humans present this biological form in their life cycles, such as Cryptosporidium spp. (TYZZER, 1907), T. gondii (DUBEY et al., 1970) and Cyclospora spp. (ORTEGA et al., 1993). One of the main difficulties when working with environmental samples is the fact that many samples go through adverse conditions such as intense sun and low humidity, favoring alterations in the morphologies and metabolism of the microorganisms, hindering the diagnosis by conventional microscopy and sporulation, respectively.

Mites were found in three samples and are the most important aeroallergens in tropical climate regions; they are associated with respiratory allergies, such as allergic asthma and rhinitis. In addition, they can contaminate food, especially if kept in hot and humid environments, facilitating their proliferation. When ingested, they can trigger allergic reactions and anaphylaxis in atopic individuals, so their presence in vegetables presents a potential risk to human health (GELLER et al., 1995; 2009).

A total of $45.23 \%(19 / 42)$ of the vegetables were contaminated by parasites. Cultivation in direct contact with the soil can facilitate this contamination, since these parasites are commonly found in the soil (SILVA et al., 2016b) and animal manure used for fertilization (FERNANDES et al., 2015). Strongyloides spp. are opportunistic parasites of animals. The presence of Strongyloides spp. deserves special attention because 
Strongyloides stercoralis have the capacity to infect humans, mainly immunocompromised individuals (MAIA et al., 2006; SILVA et al., 2016b).

Among the techniques used, a greater percentage of positive results were observed when using the Hoffman et al. (1934) technique. This may have occurred because the test was more sensitive to the parasites found relative to the other methods. A greater sensitivity by the test was also observed by Mesquita et al. (2015) in a study carried out in community gardens in the state of Piauí, Brazil, when they used both the Hoffman et al. (1934) and Willis (1921) methods.

All the properties included in the study had domestic animals; in five of them, the animals had access to the vegetable gardens. Domestic and wild animals are important sources of contamination of soil and water (CASSENOTE et al., 2010; WELLS et al., 2015). The most significant elimination pathway of endoparasites is fecal (NEWELL et al., 2010), which justifies the need to prevent the access of animals to cultivated areas.

A statistical association between sewage destination and positive results was observed in at least one of the parasitological methods used. The form of sewage destination is of extreme importance so that feces do not contaminate the soil and the source of irrigation water (NEWELL et al., 2010; TIYO et al., 2015). The cesspool is the worse sanitary type compared to the septic tank or septic sump biodigester. This is because the cesspool allows slow degradation of pathogens due to anaerobic digestion, and due to the possibility of diffusion of fecal material into the soil, to depths of three meters and a radius of one meter and to groundwater, in which dispersion varies according to the flow level. To avoid risks to the health, safety recommendations must be followed, such as the construction of a cesspool on the lowest ground with a minimum distance of $15 \mathrm{~m}$ from any source of water and as far away as possible from cultivation sites (BRASIL, 2007). In conclusion, the presence of parasites in the vegetables, even if apathogenic, may indicate fecal contamination; the main points associated with this contamination were the use of contaminated water for irrigation and the types of sewage destination; the latter may be responsible for soil and water contamination.

\section{Acknowledgment}

To CNPq to granting of scholarship.

\section{References}

ABREU, E. S.; LIMA, M. B. A.; MACHADO, A. D.; PERSOLI, L. B. L. Análise da qualidade parasitológica de alfaces orgânicas comercializadas em uma rede de supermercados do município de São Paulo-SP. Revista da Universidade Vale do Rio Verde, Três Corações, v. 14, n. 2, p. 516-521, 2016.

ARBOS, K. A.; FREITAS, R. J. S.; STERTZ, S. C.; CARVALHO, L. A. Segurança alimentar de hortaliças orgânicas: aspectos sanitários e nutricionais. Ciência e Tecnologia de Alimentos, Campinas, v. 30, n. 1, p. 215-220, 2010.

BRASIL. Manual de saneamento: orientações técnicas. 2007. Disponível em: <http://bvsms.saude.gov.br/bvs/publicacoes/ manual_saneamento_3ed_rev_p1.pdf $>$.

BRASIL. Manual prático de análise de água. 2013. Disponível em: <http://www.funasa.gov.br/site/wp-content/files_mf/manual_ pratico_de_analise_de_agua_2.pdf $>$.

CARELI, R. T. Ocorrência de Cryptosporidium spp. na cadeia produtiva de alface (Lactuca sativa $\mathrm{L}$.) sua captura e retenção por biofilmes de Pseudomonas fluorescens e seu controle por surfactantes. 2009. 154 f. Tese (Doutorado em Ciência e Tecnologia de alimentos) - Universidade Federal de Viçosa, Viçosa. 2009.

CACCIÒ, S. M.; CHALMERS, R. M.; DORNY, P.; ROBERTSON, L. J. Foodborne parasites: outbreaks and outbreak investigations. A meeting report from the European network for foodborne parasites (Euro-FBP). Food and Waterborne Parasitology, Amsterdam, v. 10, p. 1-5, 2018.

CASSENOTE, A. J. F.; NETO, J. M. P.; CATELANI, A. R. A. L.; FERREIRA, A. W. Soil contamination by eggs of soil-transmitted helminths with zoonotic potential in the town of Fernandópolis, State of São Paulo, Brazil, between 2007 and 2008. Revista da Sociedade Brasileira de Medicina Tropical, Uberaba, v. 44, n. 3, p. 11-14, 2010.

CONAMA. Ministério do Meio Ambiente. Conselho Nacional do Meio Ambiente. Resolução no 357, de 17 de março de 2005. Disponível em: < http://www.mma.gov.br/port/CONAMA/res/res5/ res35705.pdf $>$.

DEAN, A. G. Epi-Info, Version 5: a word processing, database, and statistics programme for epidemiology on microcomputers. Atlanta: Centers for Disease Control and Prevention, 1990. 391 p.

DUBEY, J. P.; MILLER, N. L.; FRENKEL, J. K. Characterization of the new fecal form of Toxoplasma gondii. Journal of Parasitology, Lawrence, v. 56, n. 3, p. 447-456, 1970.

ESTEVES, F.; FIGUEIRÔA, E. Detecção de enteroparasitas em hortaliças comercializadas em feiras livres do município de Caruaru (PE). Revista Baiana de Saúde Pública, Salvador, v. 33, n. 2, p. $38-47,2012$.

FAUST, E. C.; SAWITZ, W.; TOBIE, J.; ODOM, V.; PERES, C.; LINCICOME, D. R. Comparative efficiency of various technics 
for the diagnosis of protozoa and helminths in feces. Journal of Parasitology, Lawrence, v. 25, n. 3, p. 241-262, 1939.

FERNANDES, N. D. S.; GUIMARÃES, H. R.; AMORIM, A. C. S.; REIS, M. B. Avaliação parasitológica de hortaliças: da horta ao consumidor final. Saúde e Pesquisa, Maringá, v. 8, n. 2, p. 255 265,2015 .

FERREIRA, F. P.; CALDART, E. T.; FREIRE, R. L.; MITSUKABREGANÓ, R.; FREITAS, F. P.; MIURA, A. C.; MAREZE, M.; MARTINS, F. D. C.; URBANO, M. R.; SEIFERT, A. L.; NAVARRO, I. T. The effect of water source and soil supplementation on parasite contamination in organic vegetable gardens. Revista Brasileira de Parasitologia Veterinária, Jaboticabal, v. 27, n. 2, p. 327-337, 2018 .

FRANCO, B. D. G. de M.; LANDGRAF, M. Microbiologia dos alimentos. São Paulo: Atheneu, 2003. 182 p.

GELLER, M.; ESCH, R. E.; FERNÁNDEZ CALDAS, E. Respiratory atopy and domestic mite sensitization in Rio de Janeiro. Revista Brasileira de Alergia e Imunopatologia, São Paulo, v. 18, n. 1, p. 13-18, 1995.

GELLER, M.; HAHNSTADT, R. L.; REGO, R. M.; CALDAS, E. F. Anafilaxia induzida por farinha de trigo contaminada por ácaros Dust mite-contaminated wheat flour induced anaphylaxis. Revista Brasileira de Alergia e Imunopatologia, São Paulo, v. 32, n. 5, p. 199-201, 2009.

HOFFMAN, W. A.; PONS, J. A.; JANER, J. L. Sedimentation concentration method in schistosomiasis, Puerto Rico. Journal of Public Health, Oxford, v. 9, n. 1, p. 283-298, 1934.

MAIA, T. M. C.; VASCONCELOS, P. R. L.; FAUTH, S.; MOTTA NETO, R. Strongyloides stercoralis over infestation. Revista Brasileira em Promoção da Saúde, Fortaleza, v. 19, n. 2, p. 118121, 2006.

MATOSINHOS, F. C. L. Padronização de metodologia para detecção de ovos e larvas de helmintos em alface. 2012. $98 \mathrm{f}$. Dissertação (Mestre em Parasitologia) - Universidade Federal de Minas Gerais, Belo Horizonte. 2012.

MELO, M. C. B.; KLEM, V. G. Q.; MOTA, J. A. C.; PENNA, F. J. Parasitoses Intestinais. Revista Médica de Minas Gerais, Belo Horizonte, v.14, p. 3-12, 2004.

MESQUITA, D. R. de; SILVA, J. P.; MONTE, N. D. P.; SOUSA, R. L. T.; SILVA, R. V. S.; OLIVEIRA, S. S.; LEAL, A. R. S.; FREIRE, S. M. Ocorrência de parasitos em alface-crespa (Lactuca sativa L.) em hortas comunitárias de Teresina, Piauí, Brasil. Revista de Patologia Tropical, Goiânia, v. 44, n. 1, p. 67-76, 2015.

MONTANHER, C. C.; CORADIN, D. D. C.; FONTOURA-DASILVA, S. E. Parasitologic evaluation of eggs, cysts and larval forms of enteroparasites found in lettuces (Lactuca sativa) served in buffet restaurants in Curitiba City, State of Paraná, Brazil. Estudos de Biologia: Ambiente e Diversidade, Curitiba, v. 29, n. 66, p. 63-71, 2007.

NATARO, J. P.; KAPER, J. B. Diarrheagenic Escherichia coli. Clinical Microbiology Reviews, Washington, v. 11, n. 1, p. $142-$ 201, 1998 .

NEWELL, D. G.; KOOPMANS, M.; VERHOEF, L.; DUIZER, E.; AIDARA-KANE, A.; SPRONG, H.; OPSTEEGH, M.; LANGELAAR, M.; THREFALL, J.; SCHEUTZ, F.; GIESSEN,
J. van der; KRUSE, H. Food-borne diseases - The challenges of 20 years ago still persist while new ones continue to emerge. International Journal of Food Microbiology, Summit-Argo, v. 139, Suppl. 1, p. S3-S15, 2010.

OLIVEIRA, C. A. F. de; GERMANO, P. M. L. Estudo da ocorrência de enteroparasitas em hortaliças comercializadas na região metropolitana de São Paulo - SP , Brasil. Revista Saúde Pública, São Paulo, v. 26, n. 5, p. 332-335, 1992.

ORTEGA, Y. R.; STERLING, C. R.; GILMAN, R. H.; CARNA, V. A.; DIAZ, F. Cyclospora species - a new protozoan pathogen of humans. New England Journal of Medicine, Boston, v. 328, n. 18, p. 1308-1312, 1993.

PACHECO, M. A. S. R.; SOTO, F. R. M.; FONSECA, S. K.; GOMES, A. H. S.; GIANCOLI, M.; LEITE JÚNIOR, A. P.; DIAS, H. G. G.; CANDIDO, V. L. P.; ARMELIN, I. M. Monitoramento das condições higiênico-sanitárias de alfaces produzidas no município de Ibiúna, SP. Revista Eletrônica de Epidemiologia das Doenças Transmitidas por Alimentos, São Paulo, v. 3, n. 2, p. 52-53, 2003. R CORE, T. R: a language and environment for statistical computing. 2003. Disponível em: <http://www.R-project.org>. Acesso em: 17 dez. 2018.

SANTANA, L. R. R.; CARVAlHO, R. D. S.; LEITE, C. C.; ALCÂNTARA, L. M.; OLIVEIRA, T. W. S.; RODRIGUES, B. M. Qualidade física, microbiológica e parasitológica de alfaces (Lactuca sativa) de diferentes sistemas de cultivo. Ciência e Tecnologia de Alimentos, Campinas, v. 26, n. 2, p. 264-269, 2006. SCHERER, K.; GRANADA, C. E.; STULP, S.; SPEROTTO. R. A. Avaliação bacteriológica e físico-química de águas de irrigação, solo e alface (Lactuca sativa L.). Revista Ambiente e Água, Taubaté, v. 11, n. 3, p. 665-676, 2016.

SILVA, A. F. S.; LIMA, C. A.; QUEIROZ, J. J. F.; JACOMÉ, P. R. L. A.; JÁCOME-JÚNIOR, A. T. Análise bacteriológica das águas de irrigação de horticulturas. Revista Ambiente e Água, Taubaté, v. 11, n. 2, p. 428-438, 2016a.

SILVA, A. S.; REBOUÇAS, L. T.; ALMEIDA, J. S.; ROCHA, E. V. S.; AMOR, A. L. M. Parasitological and microbiological analysis of vegetables sold in Santo Antônio de Jesus, Bahia (Brazil). Vigilância Sanitária em Debate, Rio de Janeiro, v. 4, n. 3, p. 77 85,2016 b.

TIYO, R.; SOUZA, C. Z.; NISHI, L.; BRUSTOLIN, C. F.; RATTI, B. A.; FALAVIGNA GUILHERME, A. L. Water from different sources used for the irrigation of vegetables to be marketed: research on Cryptosporidium spp., Giardia spp., and coliforms in Paraná, Brazil. Revista do Instituto de Medicina Tropical de São Paulo, São Paulo, v. 57, n. 4, p. 333-336, 2015.

TYZZER, E. E. A protozoan found in the peptic glands of the common mouse. Proceedings of the Society for Experimental Biology and Medicine, Malden, v. 5, n. 1, p. 12-13, 1907.

VOLLKOPF, P. C. P.; LOPES, F. M. R.; NAVARRO, I. T. Ocorência de enteroparasitas em amostrasde alface (Lactuca sativa) comercializadas em Porto Murtinho - MS. Arquivos de Ciências Veterinárias e Zoologia da Unipar, Umuarama, v. 9, n. 1, p. 37-40, 2006.

WELLS, B.; SHAW, H.; HOTCHKISS, E.; GILRAY, J.; AYTON, R.; GREEN, J.; KATZER, F.; WELLS, A.; INNES, E. Prevalence, 
species identification and genotyping Cryptosporidium from livestock and deer in a catchment in the Cairngorms with a history of a contaminated public water supply. Parasites \& Vectors, London, v. 8, n. 1, p. 1-13, 2015.

WILLIS, H. H. A simple levitation method for the detection of hookworm ova. Medical Journal of Australia, Sydney, v. 2, n. 18, p. $375-376,1921$. 